\title{
Biodegradation of Waste Lubricating Oil by Bacteria Isolated from the Soil
}

\author{
*H, Umar, **A. Umar, ***U. J. Ujah, ****Hauwa B., ****Sumayya B. I., \\ $* * * *$ Shuaibu M. and ****M.S. Yakubu \\ *c $\%$ Mohd Waziri, Federal Polytechnic, Bida \\ **Ahmadu Bello Academy, Sokoto \\ ***FUT Mina \\ ****Department of Natural Sciences, The Polytechnic of Sokoto State, Sokoto
}

\begin{abstract}
Oil polluted soil sample were collected from mechanical workshops and analyzed for the presence of waste lubricating oil utilizing bacteria. Waste lubricating oil utilizing bacteria were identified as pseudomonas fluoresns, Bacillus mycoides and Acinetobacter sp. Isolates were tested for potentials to degrade waste lubricating oil in mineral salt medium and the result revealed that oil was degraded at varying rates. The bacterial degraded $54.8 \%$ - $71.9 \%$ of the oil after 7 Days. The waste lubricating oil utilizing bacteria were able to emulsify the waste lubricating oil indicating that the organism may be useful in the production of bio surfactants.
\end{abstract}

\section{Introduction}

Oil released into the environment is well recognized problems in today's world. Oil spills affect many species of plants and animals in the environment, as well as humans. The search for efficient and effective method of determining the rate and total extent of biodegradation of waste lubricating oil in the soil or contaminated sites has intensified in recent years. The bacteria metabolize the oil in much the same way human converts food into energy. The soil is habitat to many living organisms; any change in their number or form may upset or cause a total collapses in the ecosystem. The effect of oil spill on soil leads to enrichment of the soil degrading microbial population. No single micro-organism has been found to be able to completely degrade a petroleum hydrocarbon molecule; however different species or strains of the same species may be capable of degrading different groups of hydrocarbons found in oil (Facundoet al.,2001).Different naturally occurring species of pseudomonas is known to contain plasmid with the relevant genes for degradation of different hydrocarbons (Jawetz et al., 1999)

Biodegradation is attractive method for the remediation of contaminated site because of its economic viability and environmental soundness (Dinklaet al., 2004).

Biodegradation is an attractive method for the remediation of contaminated site because of its economic viability and environmental soundness (Dinklaet al.,2004). Biodegradation means the breakdown of organic compounds by indigenous members without any artificial means or biologically. Oil degradation could therefore, be stimulated by seedling oil polluted soil with microorganism that have been tested and Found to possess considerably high ability in waste lubricating oil. The advantages of biodegradation include inexpensive equipment, environmentally friendly nature of the process and simplicity (Nadeau et al, 1993).

However, a disadvantage of this process has been a slow rate in achieving results. Bioremediation is a method used to treat environments polluted with organic or inorganic substances and bioremediation works by providing these pollutant-eating organisms with fertilizer, oxygen and other conditions that encourage their rapid growth (Environmental Enquiry, 2004). Bioremediation of a contaminated site is typically achieved in one of two ways. In the case described, ways are found to enhance the growth of whatever pollution eating microbes that might already have been living at the contaminated site (referred to as bio stimulation). In the second less common case, specialized microbes are added to degrade contaminant referred to as (bio augmentation). Depending on the site and its contaminant, bioremediation may be safer and less expensive than alternative solution such as incineration or land filling of the contaminated materials (Environmental Enquiry, 2007).

Bio augmentation also involve the addition of native microbial culture or inoculant to the matrix to enhance or replace the native microbial population. Single isolated microorganisms or mixed microbial cultures have been used for this purpose (Innovative Technology Group, ITG, 2003). Also noting that the extent of the biodegradation and the rate at which it occurs depends on the interaction between the environment, number and type of microorganism present (Atlas, 1998) and chemical structure of the contaminant (Walker and Crawford, 2004;

Waste lubricating pollutes the Nigerian environment due to the activities of mechanics that dump the waste oil indiscriminately. The effects of such practice are quite obvious. The vegetation and microbial flora are 
adversely affected. Surrounding water sources particularly wells may be polluted. Therefore, this study was necessary to identify bacteria which could be used to rehabilitate soil polluted with waste lubricating oil.

\section{MEDIA USED}

\section{Material And Methods}

(i) Nutrient broth

$\begin{array}{ll}\text { Lab-lemco powder } & 1.0 \mathrm{~g} \\ \text { Peptone } & 5.0 \% \\ \text { Sodium chloride } & 5.0 \% \\ \text { Distilled water } & 1 \text { litre } \\ \text { pH } & 6.0\end{array}$

$2.5 \mathrm{~g}$ of Nutrient broth was dissolved in $100 \mathrm{ml}$ of distilled water $5 \mathrm{ml}$ was distributed in Mcconkey and sterilized by autoclaving at $121^{\circ} \mathrm{C}$ for 15 minutes. This medium was used for growth of bacterial isolates.

(ii)

$\begin{array}{ll}\text { mineral salt medium } & \\ \mathrm{K}_{2} \mathrm{HPO}_{4} & 1.8 \mathrm{~g} / 1 \\ \mathrm{NH}_{4} \mathrm{CL} & 4.0 \mathrm{~g} / 1 \\ \mathrm{MgSO}_{4} \cdot 7 \mathrm{H} 2 \mathrm{O} & 1.2 \mathrm{~g} / 1 \\ \mathrm{NaCL} & 0.1 \mathrm{~g} / 1 \\ \mathrm{KH}_{2} \mathrm{PO}_{4} & 1.2 \mathrm{~g} / 1 \\ \mathrm{FeSO}_{4} 7 \mathrm{H}_{2} \mathrm{O} & 6.04 \\ \text { Agar-agar } & 10 \mathrm{~g} \\ \text { Waste lubricating oil } & 0.25 \mathrm{ml} \\ \text { Distilled water } & 100 \mathrm{ml} \\ \text { pH } & 7.4\end{array}$

\section{.Sample Collection}

Oil contaminated soil was collected from mechanic workshops at Okada Road, Kpakungu and KeteriGwari Road, Minna, Niger State Nigeria. At each sampling point, three samples were collected at a depth of $10 \mathrm{~cm}$ and bulk samples were collected in polythene bags and immediately transported to the laboratory for analysis.

\section{Determination of $\mathrm{pH}$ of soil}

The $\mathrm{pH}$ was determined using a $\mathrm{pH}$ meter (Crison micro $\mathrm{pH} 2000$ model). 2.5g of each soil sample was suspended in $20 \mathrm{ml}$ of distilled water mixed well. The $\mathrm{pH}$ meter was standardized using phosphate buffer solution after which the $\mathrm{pH}$ were determined in duplicates.

\section{Enumeration of Bacteria}

Serially diluted samples were planted on Nutrient agar (NA) for the enumeration of aerobic heterotrophic bacteria. The colonies were counted and pure cultures were obtained by repeated sub-culturing and maintained on agar slants for further characterization and identification.

\section{Characterization and Identification of isolates}

The bacteria isolates were characterized by colonial morphology and biochemical tests. These were compared with known taxa to identify the isolates. The biochemical tests are described below:

\section{(i) Gram staining}

A clean and grease free slide was gottenand a dropof normal saline was place at the edge of the slide. A wire loop was then flamed and of the bacteria colony was picked and mixed homogeneously with normal saline. It was allowed to air dry and then it was heat fixed using a Bunsen. Crystal violet was flooded on the slide (primary stain) and allowed to stain for 1 minute. It was then placed with lugols iodine for 1 minute (this act as mordant). The iodine was then decolorized with absolute alcohol then washed with water until no more violet runs from slide.

The smear was then counter stain with safaranine (secondary stain) and allowed to dry and it was then observed under the microscope using x 100 oil immersion objective.

(ii) Catalase test: Using a glass slides placed flat on the surface of the

table, a drop of 3\% of hydrogen peroxide was placed on the center of the slide the using a sterile inoculating loop, a portion of the culture was transferred onto the drop of hydrogen peroxide. The immediate evolution 
of gas (oxygen) bubbles indicates a positive reaction although some cultures are slow catalase producers and had to be observed for few minutes before the positive result was obtained, while negative catalase producers did not liberate oxygen bubbles.

(iii) Oxidase test: $1 \%$ solution of aqueous tetramethyl-p-phenylene

diamine hydrochloride. (the regent used) this test is particularly useful for differentiating pseudomonas from certain other enteric or gram negative bacteria. On a nutrient agar plate containing 24 hours culture streaking from a nutrient agar slant, a few drops the reagents was placed on the line of streaking of each culture. Oxidase positive colonies developed a pink colour which progressively became purple within 30 seconds, while oxidase negative colonies did not produce this purple colouration.

(iv) Citrate utilization: This test is used for differentiation of coliform bacteria by their ability to utilize citrate as sole of carbon. Using simmons citrate agar (oxoid), stab in test tube, the colony was stabbed into the agar and incubated at $37^{\circ} \mathrm{c}$ for 24 hour. Colour change of the citrate agar indicator from green to blue, indicate positive citrate utilization while negative had no colour change.

(v) Urease activity: The urea agar (oxoid) slant in tubes were

inoculated with the pure cultures from the nutrient agar slants and incubated at $37^{\circ} \mathrm{c}$ from 24 hours. A change in the colour of the urea agar form yellow to red, which was due to the release of urea, hydrolyzing urea to release ammonia that resulted in increase $\mathrm{pH}$ indicate a positive urease activity.

(vi) Triple sugar Iron (T.S.I) test: The TSI agar (oxoid) slant in tubes were inoculated with pure culture from the nutrient agar slants and incubated at $37^{\circ} \mathrm{c}$ for 24 hours. A change in the colour of the slant from red to yellow indicated utilization of glucose recored as A, while an absence of colour change was recorded as K. A colour change in the butt from red to yellow, indicated utilization of lactose and/or sucrose recorded as a, while absence of colour change was recorded as K. therefore, utilization of all sugars was recorded as $\mathrm{A} / \mathrm{A}$ and the lack of utilization of any sugar was recorded as $\mathrm{K} / \mathrm{K}$. But, utilization of one of the sugar was recorded as $\mathrm{K} / \mathrm{A}$ or $\mathrm{A} / \mathrm{K}$ depending on which sugar was utilized, with result for glucose utilization as the numerator and the lactose or sucrose as denominator.

\section{Screen Test of Isolates for Potential to Utilize Waste Lubricating Oil}

The isolates were grown in nutrient both for 24hours and incubated at room temperature. Mineral salt medium was prepared and $5 \mathrm{ml}$ was dispensed into each test tube. Waste lubricating oil $(0.05 \mathrm{ml})$ was added to it. It was therefore sterilize by autoclaving at $121^{\circ} \mathrm{C}$ for 15 minutes. $0.1 \mathrm{ml}$ of nutrient broth growth culture of bacteria was added into the mineral salt medium and waste lubricating oil. It was then incubated at room temperature without shaking (stationary) for seven days. Two test tubes were added without inoculating the organism and serve as control. The test tubes were observed for turbidity (which indicates the growth of the organism). The extent of utilization of the incorporated waste lubricating oil was revealed as:

No growth, + minimal growth, ++ moderate growth, +++ maximum growth, ++++.

\section{Biodegradation of waste lubricating oil}

The amount of waste lubricating oil degraded in the soil was determined by the weight loss method of Bossert and Bartha (1984). This was done by suspending $3 \mathrm{~g}$ of soil in $10 \mathrm{ml}$ of diethylether in Erlenmeyer flask and shaken vigorously to extract the oil. The solvent - oil mixture was transferred into a pie weighed beaker. This was done until all the oil was extracted from the soil. The solvent - oil mixture was exposed at room temperature overnight to allow the solvent to evaporated completely. The new weight of the beaker containing residual oil was taken and the percentage of oil degraded was calculated (Ijah and Ukpe, 1992). Thus:

$\%$ biodegradation $=$ weight of oil $($ control $)-$ weight of oil (degraded $) \times 100$ weight of oil (control)

\section{Result}

\section{pH and Temperature of Soil Sample}

The $\mathrm{pH}$ of the soil samples collected from waste lubricating oil polluted site is presented in Table 1 . The $\mathrm{pH}$ ranged from 5.69 to 6.26 meaning that the soil was acidic in reaction. The temperature ranged from $23^{\circ} \mathrm{C}$ to $30^{\circ} \mathrm{C}$ (Table 1 ).

\section{Bacterial counts in soil}

The bacterial counts in soil collected from polluted sites are presented in Table 2. The result revealed that the aerobicheterophic bacteria counts range from $1.5 \times 10^{5} \mathrm{cfu} / \mathrm{g}$ to $5.2 \times 10^{5} \mathrm{cfu} / \mathrm{g}$. while oil utilizing bacterial ranged from $2.0 \times 10^{2} \mathrm{cfu} / \mathrm{g}$ to $5.0 \times 10^{2} \mathrm{cfu} / \mathrm{g}$.

\section{Identification of Bacteria and their waste lubricating Oil Utilizing potential.}


The bacteria were identified as pseudomonas fluoresns, Bacillus mycoides and Acinetobactersp (Table 3). All the bacterial isolates obtained were able to utilize waste lubricating oil at moderate as a source of carbon and energy (Table 4). It was observed that the isolates utilized the oil after 3 days of lag period.

\section{Biodegradation of waste Lubricating oil by Bacteria}

The bacteria degraded the waste lubricating oil to a varying extent.

The extent of oil biodegradation ranged from $64.8 \%$ to $71.9 \%$ (Table 5). It was observed that AcinetobacterspDegrade the waste lubricating oil considerably higher that other Table 1: $\mathrm{pH}$ and temperature of polluted soil samples collected from mechanic workshops in Minna.

Table 1: pH and Temperature of polluted soil samples collected frommechanicwork shops in Minna.

\begin{tabular}{lll}
\hline Coded polluted soil sample & $\mathrm{pH}$ value & Temperature $\left({ }^{0} \mathrm{c}\right)$ \\
\hline OKD1 & 5.69 & 26 \\
OKD2 & 6.08 & 23 \\
KPG3 & 6.05 & 30 \\
KPG4 & 6.11 & 27 \\
KTG5 & 5.83 & 28 \\
KTG6 & 6.26 & 27 \\
\hline
\end{tabular}

Key: OKD - oil polluted soil sample collected from Okada Road mechanic workshop.

KPG - oil polluted soil sample collected from Kpakungu Road mechanic workshop.

KTG - oil polluted sample collected from KeterinGwari Road mechanic workshop

Table 2: counts of bacteria in soil samples collected from mechanic workshops in Minna.

Coded polluted soil sample No Aerobic hetetrophic

\begin{tabular}{ll} 
& Bacteria $\left(\mathrm{x} 10^{5} \mathrm{cfu} / \mathrm{g}\right)$ \\
\hline OKD1 & 4.8 \\
OKD2 & 3.0 \\
KPG3 & 5.2 \\
KPG4 & 3.5 \\
KTG5 & 3.0 \\
KTG6 & 3.5 \\
\hline
\end{tabular}

KEY;

OKD- $\quad$ oil polluted soil sample collected from Okada Road mechanic workshop.

KPG- $\quad$ oil polluted soil sample collected from Kpagungun Road mechanic workshop.

KTG- oil polluted soil sample collected from Keteringwari Road mechanic workshop.

Table 3: Characterization and identification of waste lubricating oil utilizing bacterial isolates

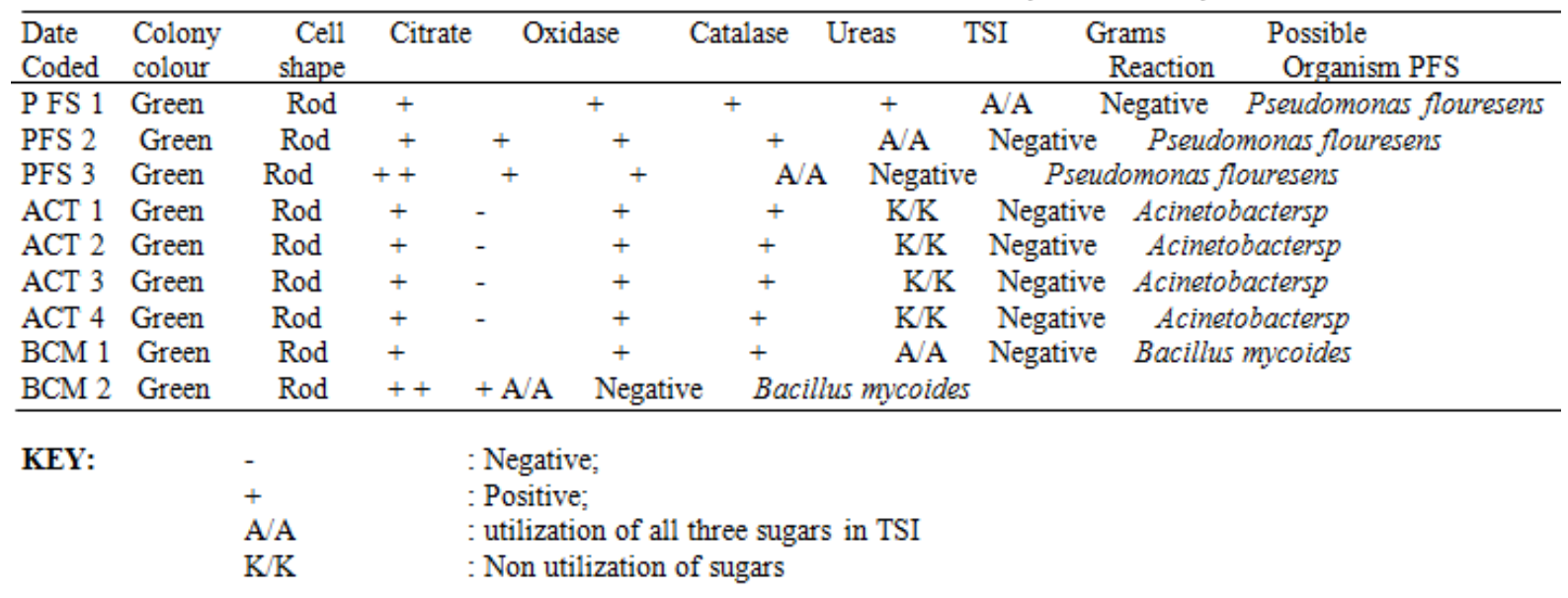


Table 4: Screen test of bacteria Isolates for potential to utilize waste lubricating oil.

\begin{tabular}{|c|c|c|}
\hline \multirow{2}{*}{ Coded bacteria isolate } & Growth first observed after & \multirow{2}{*}{$\begin{array}{r}\text { Growth in waste lubricating oil } \\
\text { after } 7 \text { days }\end{array}$} \\
\hline & (days): & \\
\hline Pseudomonas fluoresens & 3 & ++ \\
\hline \multicolumn{3}{|l|}{ PSF I } \\
\hline Pseudomonas fluoresens & 3 & ++ \\
\hline $\begin{array}{l}\text { PSF } 2 \text { Pseudomonas fluoresens } \\
\text { PSF } 3\end{array}$ & 3 & ++ \\
\hline Bacillus myxoidesBCM 1 & 3 & ++ \\
\hline Bacillus myxoidesBCM 2 & 3 & \\
\hline Ancinetobacter Sp. ACT 1 & 3 & ++ \\
\hline Ancinetobacter Sp. ACT 2 & 3 & ++ \\
\hline Ancinetobacter Sp. ACT 3 & 3 & ++ \\
\hline Ancinetobacter Sp. ACT 4 & 3 & ++ \\
\hline
\end{tabular}

Table 5: Weight loss of waste lubricating oil caused by bacteriaCoded bacteria

\begin{tabular}{lc}
\hline Coded bacteria & $\begin{array}{c}\text { Weight lost by waste lubricating oil (\%) } \\
\text { after 7 days }\end{array}$ \\
\hline Pseudomonas fluoresensPSF 1 & 65.5 \\
Pseudomonas fluoresensPSF 2 & 65.4 \\
Pseudomonas fluoresensPSF 3 & 65.2 \\
Bacillus myxoidesBCM 1 & 64.8 \\
Bacillus myxoidesBCM 2 & 65.6 \\
Ancinetobacter Sp. ACT 1 & 71.9 \\
Ancinetobacter Sp. ACT 2 & 71.9 \\
Ancinetobacter Sp. ACT 3 & 71.9 \\
Ancinetobacter Sp. ACT 4 & 71.9 \\
\hline
\end{tabular}

The Isolates, Acinetobactersp degraded $71.9 \%$ of the oil after 7 days. Pseudomonas fluoresens, degraded at $68.5 \%$ and bacillus mycoidesdegradedat $64.8 \%$ of the oil which was the least level of oil biodegradation.

\section{Discussion}

The results of the study have revealed that waste lubricating oil polluted soil sample harbored different types of bacteria. The Bacteria had the ability to utilize waste lubricating oil. This means that the bacteria can use waste lubricating oil as a source of carbon and energy. Growth of the bacteria and the weight loss of waste lubricating oil could be due to varying capabilities of the organisms to elaborate hydrocarbon degrading. The waste lubricating oil utilizing bacteria were identified as pseudomonas fluoresens, Acinetobactersp and Bacillus mycoides. These organisms have earlier been associated with oil degradation. (Bossert and Bartha, 1984; Ijah and Ukpe, 1992).

It has also reported that acinetobactersp HO1-N, has a complex mechanism for the transport and uptake of alkane and an elaborate system for packaging alkane which enter the cells, poling unmodified alkane in membrane bound inclusion (Kenedyet al.; 1975; Scott et al.; 1976; Scott and Finnerty, 1984) when compared to pseudomonassp(P. Putida), whose alkane metabolism is encoded on plasmid bone genes (Chakrabartyet al; 1973; Neider and Shapiro, 1975). These are extral chromosomal genetics element that are integrated into the chromosomes, but code for various functions are not require for the microbes life though provide additional capabilities to the microbe. Therefore implying that acinetobactersp can degrade petroleum waste components more rapidly, than pseudomonas sp. Since its alkane metabolism is coded on its chromosome. While, pseudomonas sppfirst has to undergo replication, when faced with petroleum waste pollution, to integrate it extral chromosomal plasmid coding for group specific oxygenases for alkane metabolism into its chromosome. 
The organisms are efficient oil degraders and therefore may be used in seeding oil polluted soil in the tropics. The $\mathrm{pH}$ and temperature of the polluted soil agree with earlier works by Huddleston Cresswell (1976), Hill (1978), Dibble and Barthar (1979), Degong (1980) and Vanlookeet al., (1995), respectively. However, temperature does not appear to have as much effect on degradation when compared to the other abiotic factors, since degradation has been found to occur in soil with low temperatures (Hudllestone and Cresswell, 1976).

It is obvious that, a single hydrocarbon degrading bacteria cannot completely degrade all components of petroleum waste (Obire, 1990), thus varied genera of bacteria were isolated from soil contaminated with petroleum wastes, and some degrading the parent polluting hydrocarbon and other degrade intermediate substance of primary degraders.

The soil also contribute to the hydrocarbon degrading ability, due to it varied availability of nutrient, texture, $\mathrm{pH}$, moisture content temperature and porosity which ensures the appropriate contact time between the bacteria and the polluting hydrocarbon. It is evident, however that not only bacteria take part in the degradation of these waste, but other organisms, such as fungi and protozoa. They also degrade petroleum automobile wastes (Bartha; et al., 1984, Pinholtet al., 1979), but these two organism are beyond the scope of this study.

\subsection{Conclusion}

The study has revealed that waste lubricating oil polluted soil harbored bacteria that can degrade and emulsify waste lubricating oil.Acinetobactersp were the most efficient oil degraders identified. Other oil degrading bacteria were species of Pseudomonas and Bacillus. These bacteria may be useful in seeding oil polluted environment.

\subsection{Recommendation}

It is recommended that:

(i) The organisms should be tested for the production of biosurfactants for oil spill remediation and other industrial uses.

(ii) Gas chromatographic analysis should be done on the degraded oil to find out the components of oil that has been attacked by the bacteria.

(iii) Bioremediation in the field should be conducted with the bacterial isolates to ascertain their suitability for oil cleanup operation.

\section{References}

[1]. Alexandra, M. (1977).Introduction to Soil Microbiology John Wiley and Sons, New York.

[2]. Atlas, R. M. (1989). Microbial degradation of petroleum hydrocarbons: An environmental perspective, Microbiological Review; 45:180- 2009 .

[3]. Atlas, R. M., Sexstone, A., Gustin, P., Miller, O., Linkins P., and Everett, K.(1978). Biodegradation of crude oils By Tundra soils microbes. In Biodeterioration: precedings of the Fourth International Symposium. Berlin (T.A Oxley, D. Allsop and G. Backer, eds). Pp. $21-28.21-28$. pitman, London.

[4]. Bossert, I. and Bartha, R. (1984).Fate of Petroleum in soil ecosystem. In Petroleum Microbiology (Atlas, R. M. ed.), Mcmillian Publishing Company, New York, PP. 435 - 473.

[5]. Dejong, E. (1980). The effect of crude oil Spill on cereals.Environmental Pollution Series, 22:187 - 196.

[6]. Dibble, J. T. \&Bartha, R. (1979). Effect of environmental parameters on the Biodegradation of oil sludge. Applied and Environmental Microbiology, 37:729-739.

[7]. Dinkla, I. J. T., Gabor, E.M. and Janssen, D. B. (2004). Effect of ion limitation on the degredation of toluene by Pseudomonas strains carrying TOL, (PWWO) Plasmid. Applied environmental, Microbiology, 67:3406 - 3412.

[8]. Environmental Inquiry (2004). Bioremediation Online at http://ei.cornell.edu/biodeg/bioremed/

[9]. Facundo, J. M. R., Vanessa, H.R. and Teressa, M.L., (2001). Biodegradation of waste lubricating oil in soil by microbial consortium. Water, Air and Soil Pollution, 128:313 - 320.

[10]. Ijah, U.J.J. and Ukpe, L.I. (1992). Biodegradation of crude oil by Bacillus Strains 28A and 61B isolated from oil spilled soil. Waste management 12(1):55 - 60.

[11]. Jawetz, E., Melnick, J. L., Adelberg, E.A., Brooks, G.F., Buttel, S. J. and Ornston, I. N. (1999).Pseudomonas, and uncommon Gram Negative. In:

[12]. Jewetz, E., Melnick, J. L., Adelberg E.A., Brooks, G.F., Buttel, S. J. and Ornston, L.N. (editors). Review of MedicalMicrobiology, 19th edn. Appleton and Langue Publishing, Prentice Hall, California, USA, pp. $224-229$.

[13]. Nadeau, R. R., Singhvi, J., Ryabik, Y., Lin. I. and Syslo.J. (1993). Monitoring for bioremediation efficacy: The Narrow Mash Experience. Proceedings of the Soil Spill Conference.American Petroleum Institute, Washington D.C., pp. 447 -4485.

[14]. Nigeria National Petroleum Cooperation NNPC (2004). Petroleum Exploration and Development in Nigeria. NNPC, Lagos.

[15]. Nigeria National Petroleum Cooperation, (2007).Petroleum Exploration and Development in Nigeria NNPC, Lagos.

[16]. Oyem, A. (2001) Christian Call for Action in Nigeria Oil Spill. Sage Oxford Christian Environmental Group, Ikeja, Lagos State, Nigeria.

[17]. Walker, M. V. and Crawford, R. L., (1997). Overview: Biotransformation and Biodegradation. In: Hurst, C.J., Kundsen, G.R., Mcierney, M.J., Stetzenbach, L. D. and Walker, M. V. (eds). Manual of Environmental Microbiology. American Society for Microbiology Press, Washington, D.C., pp. $707-708$.

[18]. Wikipedia (2007).Biodegradation of crude oil.Online at http://www.wikipedia.org. 